\title{
An Empirical Investigation of the Impact of Institutions on Economic Growth
}

\author{
Dr. RUMMANA ZAHEER \\ Associate Professor, Department of Economics, University of Karachi Pakistan. \\ Email: rummanazaheer@yahoo.com
}

ADEELA KHALID

Department of Economics, University of Karachi Pakistan.

Email: adeelakhalid01@gmail.com

\begin{abstract}
This paper explores the impact of institutions on economic growth, measured in terms of Gross Domestic Product (GDP) per capita. A wide range of economic, non-economic, social, environmental and political factors contribute to economic growth and prosperity. Institutions are discussed as a range of array of regulatory and accountability mechanisms, beyond the boundaries of market functioning. This paper takes composite values of democracy index, vested interests, accountability, human rights and freedom of association and uses it as a proxy for institutions. A range of theoretical and empirical evidence, in addition to panel data analysis indicates positive role of institutions in economic growth.
\end{abstract}

Keywords: Institutions, Democracy, Economic Growth, Investment, Fertility, Education, Inequality, Education, Government, Political Stability, Rule of Law, Life Expectancy, Panel Data.

\section{Introduction}

Over the last few decades, the varying degree of economic growth across the globe raises concerns and questions about validity of contributing and influencing factors. Several attempts have been made to explore the root causes of economic prosperity and growth. Countries with similar GDP growth rates are not necessarily exhibit the same levels of socio-economic dynamics, human development indicators and wellbeing measures. Traditional economic factors including trade openness, capital share per capita, investment ratios, government consumption, black market premium and infrastructure are usually considered conducive for economic growth. Geography, distance with equator, race or ethnic background, colonial history, governance structures and even choice between socialism and capitalism are some of the much-discussed non-economic factors for economic growth. On the basis of these broad categories, several researchers and economists, especially North (1998), Rodrick (2000) and Barro (1996) have come up with the notion of role of institutions in economic growth. Institutions are formal and informal rules to govern interactions among individuals. North defines institutions as "a set of rules, compliance procedures, moral and ethical behavioural norms designed to constrain the behaviour of individuals in the interests of maximising the wealth or utility of principals" (North 1998, pp 201-202). Furthermore, North (1990, p.4) elaborates "Institutions are the rules of the game in a society, ... the humanly devised constraints that shape human interaction ... They structure incentives in human exchange, whether political, social or economic". Role of institution on economic growth is analysed on the basis of cross-country empirical evidence and extensive relevant literature (Acemoglu, Johnson and Robinson, 2001). This paper explains the importance of institutions for economic growth through looking at cross-linkages of human, social, physical and political capital. Institutions support processes and mechanisms for contract enforcement, protection of property rights, education and health systems, democratic structures, rule of law, and market functioning. 
Panel data of 32 countries is used to investigate the question, on the basis of theoretical and econometrical analysis. The next section is theoretical overview based on literature review, followed by empirical analysis with explanation of variables and model specification. Fourth section carries model estimation and statistical inference of the model which leads to concluding section.

\section{Literature Review}

There is a great deal of literature ${ }^{1}$ available on the factors which contribute to economic growth and subsequently institutions have emerged as one of the main forces. Focus on institutions gained momentum in 1960s mainly with the works of Ronald Coase, Douglass North and Harold Demsetz. Historically, institutions used to be taken as orthodox structures supposedly to be uniformed across the world but this has transformed over the years to search for uniqueness and customisation of institutions. Around 1990s the role of institutions emerged as a positive player in economic development, however, there are still ambiguities that which institutions are significant to steer the process of economic growth.

Institutions are both formal and informal, where formal institutions comprise of legal and political structures and written rights including laws, constitution, policies etc. On the other hand, informal institutions include culture, norms and conventions backed by social customs (Sobel, R. and Coyne, C. 2011). Both formal and informal institutions cannot work in isolation. Formal institutions are heavily dependent on informal institutions for their functioning. (de Soto 1989; Boettke, Coyne, and Leeson 2008; Williamson 2009).

Institutions don't just exist; they evolve and transform. The quality and efficiency of institutions vary across regions and even within countries. Institutions don't function in silos. They are inter-connected with other institutions in a country operating in the presence of several endogenous and exogenous factors. Williamson (2000, pp 596-600) illustrates hierarchy of social analysis to map the impact of institutions on economic growth with level of social analysis. Hierarchy of social change is inversely proportional to the time required to change.

Table 1 Co-integrating institutions - Williamson's Hierarchy of Social Analysis

\begin{tabular}{|lll|}
\hline Level & Description & Time to change \\
\hline $\mathbf{1}$ & $\begin{array}{l}\text { Embeddedness: informal institutions, customs, traditions, norms, } \\
\text { and religion }\end{array}$ & $100-1000$ years \\
$\mathbf{2}$ & $\begin{array}{l}\text { Institutional environment: formal rules of the game, especially } \\
\text { property (polity, judiciary, and bureaucracy) }\end{array}$ & $10-100$ years \\
$\mathbf{3}$ & $\begin{array}{l}\text { Governance: play of the game, especially contract (aligning } \\
\text { governance structure with transactions) }\end{array}$ & $1-10$ years \\
$\mathbf{4}$ & $\begin{array}{l}\text { Resource allocation and employment (prices and quantities, } \\
\text { incentive alignment) }\end{array}$ & Continuous \\
\hline
\end{tabular}
Source: Williamson (2000, pp 596-600)

World Bank's 2002 report on Building Institutions for Markets, merely looks at the economic side of institutions, from neoliberal perspective. Previously the 'one size fits all' prescriptions of the international financial institutions almost failed because most of the programmes ignored the differences in institutions across the world (Chang 2007). Adding on, the financial crises in different countries ${ }^{2}$ around end of the century, motivated the need for institutions which are able to prevent and cope with such crises. It paved the way for IMF and World Bank to come up with 'governance related conditionalities' to their financial

${ }^{1}$ Barro 1996; Aron 2000; Acemoglu, Johnson, and Robinson 2001, 2002; Glaeser et al. 2004; Rodrik, Subramanian, and Trebbi 2004; Acemoglu and Johnson 2005; Gwartney, Lawson, and Holcombe 1999; Ovaska and Sobel 2005; Sobel, Clark, and Lee 2007.

${ }^{2}$ Mexico 1995, Asia 1997, Russia 1998, Brazil 1999, Argentina 2002. 
assistance programmes which led to global standardization of institutions. The institutions directly controlling economic factors contribute significantly to economic growth. Property rights, technological change, resource allocations and specialised production are key institutional arrangements for economic growth. Transaction costs of trade is a key element of economic performance (North 1989). Rodrik, Subramanian, and Trebbi (2004) prioritises institutions over geography in terms of impact on economic growth.

Private-Property institutions are the main factors of economic prosperity according to Acemoglu, Johnson, and Robinson (2001, 2002). A subsequent work by Acemoglu and Johnson (2005) also talks about property institutions by emphasising the role of property rights institutions in comparison with contracting institutions for economic growth. Drury, A., Krieckhaus, J. and Lusztig, M. (2006) uses time series cross section data from 100 countries of 16 years to establish that in general, corruption has a negative impact on economy. Mauro (1995) also supports the argument that corruption reduces investment which hampers economic growth. On the contrary, some researchers see positive relationship of corruption with economy through more competition, broader tax net and increased public spending (Leff 1968, Nye 1967).

Rodrick (2000) regards democracy as 'meta institution' for economic growth. The role of democracy on economic growth is convoluted. A number of researchers have vouched for positive impact on economic growth whereas some have argued that democracy has neither negative or no impact on economic growth. Barro (1996a) defines the nonlinear relationship between democracy and economic growth that economy grows during the initial phases of political freedom but slows down when moderate level of political freedom is achieved. North (1990) argues that authoritarian elites can quarry society unless restricted by democratic institutions. Similarly, Bueno de Mesquita et al (2001) suggests that authoritarian leaders engage in cronyism and corruption because they have fewer checks. Impact of democracy on economic growth is summarised by Sirowy and Inkeles (1990: pp133) “...political pluralism acts to release energies and foster conditions conducive to change, entrepreneurial risk, and economic development".

On the contrary, neoclassical political-economy literature criticises democracy for its role for economic growth. Examples from East Asia supports the argument that authoritarian regimes elude rent seeking and politically motivated policies and mistakes (Haggard 1990). Politicians tend to reap particularistic privileges and influences policies which puts more burden on state resources, leading to decreased government efficiency (Olson, 1982; Amsden, 1989; Evans 1995; Wade, 1990). Categorical conclusion comes from Helliwell (1994) and Przeworski (2000) that there is no statistically significant relationship. However, democracy do have several indirect effects such as political stability, increased public expenditures on education and health which has positive impact on economic growth. Chang argues for a reverse causality between institutions and economic growth. On the other hand, Hayek (1944) and Friedman (1962) intertwine political and economic institutions, in addition that political freedoms lead to economic freedoms and vice versa. Gerring (2005) with the acknowledgement of complexity of the notion of democracy's indirect effects on economic growth has illustrated a simple diagram to show the pathway.

Figure 1 Journey from Democracy to Economic Growth
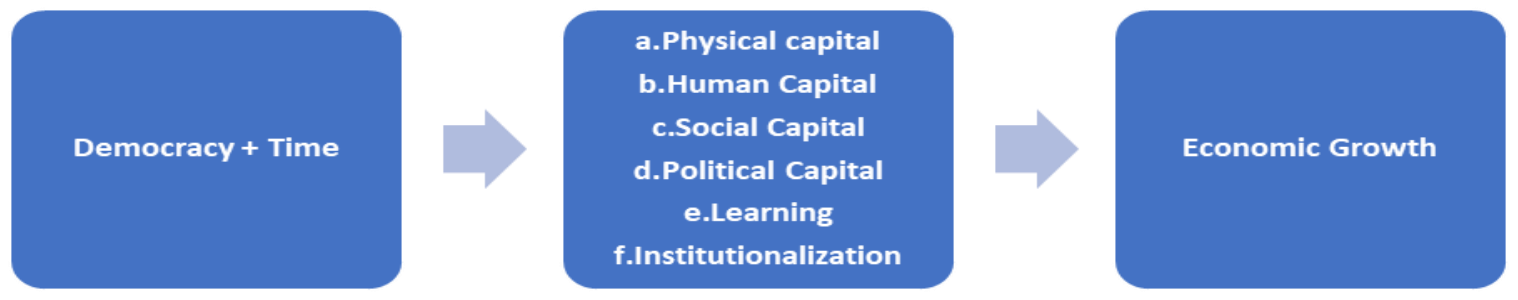

Source: Adopted from Gerrings (2005). 
Another important factor is international trade which plays key role in market formation and transformation for economic growth. Trade is regarded as a main decisive factor whether the country would grow or not (Sachs and Warner, 1995; Dollar and Kraay, 2004). The next section talks about the empirical analysis of the impact of institutions on economic growth.

\section{Theoretical Framework}

Neoclassical growth model is the basis for the framework of empirical analysis with several other factors including fertility rate, investment, openness, rule of law and size of government, in this paper. The assumption of neoclassical growth model implies, for example, diminishing returns to capital which means as economy prospers, the rate of growth slows down. If investment rate is high and population growth rate is low then economy grows fast. Distortions in rule of law, civil unrest and political instability hampers growth rate. This paper is based on the hypothesis that institutions play positive role in economic growth for the developing countries. GDP is the dependent variable and institutions are taken as the explanatory variable. There are 8 other control variables in the model, which are explained in the following section.

This paper is an attempt to build on the works by Rodrick, Barro and Acemoglu backed by a number of relevant theoretical and empirical studies. 'Democracy and Growth' by Robert J Barro (1996a) shows a panel data of 100 countries to assess the linkages of democracy and economic growth. Barro (1996a) explores the positive effects of rule of law, free markets, small government consumption, and high human capital on economic growth. When these variables and initial level of GDP is held constant, the role of democracy on economic growth is weakly negative. So, the relationship between democracy and economic growth involves the effect of political freedom on growth and standard of living on democracy. Another pioneering work of Barro (1996b) supports the notion of conditional convergence for economic growth. High initial schooling and life expectancy, lower inflation and openness to trade facilitates economic growth.

Rodrick $(2000,2004)$ provides empirical evidence for the role of institutions for economic growth. He regards democracy as a meta institution which paves the way to build economic and political institutions. Markets in order to function are backed by non-market institutions to guarantee regulations, property rights and macroeconomic stabilisation. Another key reference article is "Institutions as a fundamental cause of long run growth" by Acemoglu et al. (2005). It talks about differences in economic institutions as the cause of variation in economic development. It argues that economic institutions determine what incentives of and the constraints on economic actions and sharp economic outcomes. The paper takes the approach of Barro (1996a) and Rodrick $(2000,2004)$ to estimate the impact of institutions on economic growth.

\section{Methodology}

\section{Data and variable description}

GDP is the dependent variable with institutions as the explanatory variable. There are 8 other control variables in the model, which are explained in the following lines.

\section{The Dependent Variable}

1. Real Per Capital Gross Domestic Product (GDP): The dependent variable is real per capital Gross Domestic Product (GDP) taken as log value. The paper takes GDP as synonymous with economic growth and development. GDP is defined by World Bank as Annual percentage growth rate of GDP per capita based on constant local currency. Aggregates are based on constant 2010 U.S. dollars. GDP per capita is gross domestic product divided by midyear population. GDP at purchaser's prices is the sum of gross value added by all resident producers in the economy plus any product taxes and minus any subsidies not included in the value of the products. It is calculated without making deductions for 
depreciation of fabricated assets or for depletion and degradation of natural resources. The source for GDP data is World Development Indicators of the World Bank. It is computed on continuous values of 20 years. It is denoted by $\log G D P_{\text {it }}$ in the model.

Explanatory Variables: In this model, 'institutions' is used as independent variable.

2. Institutions: Institutions are rules, enforcement mechanism, and organizations (World Bank 2002). Since institution is a complex and multi-layered phenomenon, a proxy is used for this model. A cumulative value for Democracy index, vested interests, accountability, human rights and freedom of association is used for institution. This is the main explanatory variable of the model with positive sign which means institutions have positive impact on economic growth. Data is taken from Economist Intelligence Unit ${ }^{3}$. It is computed on continuous values of 20 years. It is denoted by $\operatorname{lns}_{\text {it }}$.

Control Variables: In this paper, 8 control variables are used, which can have influence on economic growth.

3. Fertility Rate: Fertility rate is a control variable in the model. In neoclassical growth model, a high rate of population growth has a negative effect on steady state level of output per effective worker. High population growth rate countries tend to remain in low-productivity cycle. Although fertility decisions are endogenous but an exogenous drop in birth rates can raise growth rate of per capita output (Barro 1996a). Population growth when high, tends to reduce the total capital per worker which leads to lower level of economic productivity. It is defined by World Bank as "Total fertility rate represents the number of children that would be born to a woman if she were to live to the end of her childbearing years and bear children in accordance with age-specific fertility rates of the specified year. The model predicts fertility to be a negative sign. The source for fertility rate data is World Development Indicators of the World Bank. It is computed on the basis of values of twenty years in logarithm form. It is denoted by $\log F e r_{\text {it }}$.

4. Government Consumption Ratio: Government consumption is another control variable. It covers all public-sector expenditures excluding education and military expenses. Small government sizes are hypothesized to hamper growth rates. Government consumption is said to shift resources from private sector to public sector which supposedly reduces the efficiency of resources. High government consumption requires higher inflows from taxation which reduces motivation to work or produce among the private sector which may retard growth. It is defined as "General government final consumption expenditure (formerly general government consumption) includes all government current expenditures for purchases of goods and services (including compensation of employees). It also includes most expenditures on national defence and security but excludes government military expenditures that are part of government capital formation. Data are in constant 2010 U.S. dollars.". It is estimated to carry a negative impact on economic growth. It is computed on the basis of values of twenty years. It is denoted by $G C R_{\text {it }}$.

5. Investment Ratio: Saving rate is exogenous and equal to ratio of investment to output, in neoclassical growth model. A high saving rate improves the steady state level of output per effective worker which has positive impact on growth rate. Investment ratio/saving rate is defined as "Gross savings are calculated as gross national income less total consumption, plus net transfers." Investment is estimated to be positively related to economic growth. Source of date is World Development Indicators, World Bank. It is computed on the basis of values of twenty years. It is denoted by $\ln v_{\mathrm{it}}$.

${ }^{3}$ https://www.eiu.com/home.aspx 
6. Inequality: The paper takes inequality as a control variable and uses Gini as a measure of inequality. A higher Gini coefficient signifies more inequality. Gini is a statistical measure of the degree of variation represented in a set of values, used especially in analysing income inequality. The model predicts negative sign for inequality. Inequality data is taken from World Governance Indicators, World Bank. It is computed on the basis of values of twenty years. It is denoted by Gini $i_{i t}$.

7. Political Stability: 'Political stability and absence of violence' is used as a control variable. World Governance Indicators define it as "Political Stability and Absence of Violence/Terrorism measures perceptions of the likelihood of political instability and/or politically-motivated violence, including terrorism." The model predicts positive sign for political stability. The source for Political Stability data is World Governance Indicators of the World Bank. It is computed on continuous values of 20 years. It is denoted by $S T B L_{\text {it }}$ in the model.

8. Life Expectancy: Log of life expectancy is taken as an indicator of good health, based on the general assumption that healthy workers are more efficient and productive. World Bank defines it as "Life expectancy at birth indicates the number of years a new-born infant would live if prevailing patterns of mortality at the time of its birth were to stay the same throughout its life." The model predicts life expectancy to be a positive sign. The source for data is World Development Indicators of the World Bank. It is computed on the basis of values of twenty years in logarithm form. It is denoted by logLif it.

9. Rule of Law: Rule of law is taken as an important control variable which seem to have positive correlation with economic growth. Maintenance of rule of law is favourable to growth, as advocated by Barro (1996a). It is defined as "Reflects perceptions of the extent to which agents have confidence in and abide by the rules of society, and in particular the quality of contract enforcement, property rights, the police, and the courts, as well as the likelihood of crime and violence." The model predicts positive sign for rule of law. Data is taken from World Governance Indicators, World Bank. It is computed on the basis of values of twenty years. It is denoted by $L a w_{\text {it }}$.

10. Secondary School Enrolment: Secondary school enrolment is taken as a control variable in the model. It is defined by WDI as "Gross enrolment ratio is the ratio of total enrolment, regardless of age, to the population of the age group that officially corresponds to the level of education shown. Secondary education completes the provision of basic education that began at the primary level and aims at laying the foundations for lifelong learning and human development, by offering more subjector skill-oriented instruction using more specialized teachers". The model predicts education to be a positive sign. The source for data is World Development Indicators of the World Bank. It is computed on the basis of values of twenty years. It is denoted by $S E M_{\text {it }}$.

\section{Model Specification}

The model is 'strongly balanced' with 213 observations of 32 countries, covering a period of 20 years.

Choice of Countries: The countries are chosen from three distinct regions: East Asia, Latin America and South Asia. The rationale for choosing the countries from these three regions is embedded in the following reasons: All three regions have different models for development, there is a lot of diversity among the three prescribed regions. East Asia is mainly authoritarian regions with very strong role of the state; South Asia is mainly democratic whereas, Latin America is a combination with repeated changes in governance types. The East Asian region has comparatively stronger institutions in terms of law and regulation enforcement as compared to Latin America and South Asia. Further selection of countries is based on availability of data for 10 variables. 
Timeframe: Timeframe is from 1996-2016 because data for the main explanatory variable Institutions is available from 1996 only.

Reliability of Data: The attempt has been made to use most appropriate data source in the research. However, quality of data varies across countries. In most developing countries, a large share of business transactions are cash based which are not accounted for in the national figures. Two out of three regions i.e. South Asia and Latin America may have poor quality data for some variables which may have impacted the results differently. The probability of some variables having low quality of data is mitigated through theoretical and empirical evidences from existing literature. Two variables, private property institutions and corruption which were part of the initial model, were dropped on the basis of non-availability of reliable and consistent data. The data quality for Gini for several countries is inconsistent which may cause misrepresentation of results.

Panel Data: Panel data is used for the model to control individual heterogeneity across variables. Panel data yields more information, more variability and also less collinearity among the variables, more degrees of freedom and more efficiency (Baltagi 2005). On the other hand, panel data has some drawbacks. There can be measurement errors, selectivity and/or issue of attrition. Macro panels on countries or regions with long time series that do not account for cross-country dependence may lead to misleading inference.

Hypothesis: The hypothesis of the model is Institutions play positive role in economic growth.

The model is defined as:

$\operatorname{LogGDP}_{\text {it }}=\beta_{1}$ Ins $_{\text {it }}-\beta_{2} \operatorname{LogFer}_{\text {it }}-\beta_{3} G_{C R}$ it $+\beta_{4} \operatorname{Inv}_{\text {it }}-\beta_{5}$ Gini $_{\text {it }}+\beta_{6}$ Stbl $_{\text {it }}+\beta_{7} \operatorname{LogLif}_{\text {it }}+\beta_{8} \operatorname{Law}_{\text {it }}+\beta_{9}$ SEM $_{\text {it }}+\alpha_{i}+\epsilon_{i t}$

' $i$ ' subscript is cross section countries dimension

' $\mathbf{~}$ ' subscript is time series dimension

$\boldsymbol{\alpha}_{\mathbf{i}}$ is an unobserved heterogeneity

$\boldsymbol{\epsilon}_{i t}$ is the idiosyncratic error

$\operatorname{LogGDP}_{\text {it. }}$ as $\log$ of GDP per capita growth

Ins $_{\text {it }}$ as Institutions

$\operatorname{logFer}_{\text {it }}$ as Log of Fertility Rate

$\boldsymbol{G C R}_{\text {it }}$ as Govt Consumption Ratio

$\boldsymbol{I n v _ { \text { it } }}$ as Investment Ratio

Gini $_{\text {it }}$ as Inequality Index

$S T B L_{i t}$ as Political Stability and Non-Violence

$\log _{\text {Lif }}$ it as Log Life Expectancy

Law $_{i t}$ as Rule of Law

$S E M_{\text {it }}$ as Education Enrollment

\section{Discussion}

The model is 'strongly balanced' with 213 observations over 32 countries, covering a period of 20 years with 10 variables. A number of diagnostic tests are carried out to validate the model of impact of institutions on economic growth. Data summary is provided in Appendix 1.

Multicollinearity: Multicollinearity refers to the case where there is exact linear relationship between two or more independent variables within a multiple regression, which is violation of one of Guass-Morkov 
assumptions. In presence of multicollinearity coefficient estimates are not biased but variances are biased and usual OLS procedure becomes invalid. (Wooldridge, 2009). The model is checked to prevent multicollinearity issues to bias analysis, correlation among explanatory variables is checked.

Table 2: Correlation

\begin{tabular}{|l|lllllllll|}
\hline GDP & \multicolumn{1}{l}{ INS } & logfer & GCR & INV & GINI & STBL & loglif & LAW & SEM \\
\hline INS & 1.0000 & & & & & & & & \\
$\boldsymbol{l o g}$ fer & -0.3070 & 1.0000 & & & & & & & \\
GCR & 0.0366 & 0.0709 & 1.0000 & & & & & & \\
$\boldsymbol{I N \boldsymbol { V }}$ & -0.2870 & -0.2168 & 0.2369 & 1.0000 & & & & & \\
$\boldsymbol{G I N I}$ & -0.1450 & 0.4430 & -0.2405 & -0.3445 & 1.0000 & & & & \\
STBL & 0.0081 & 0.1838 & 0.2253 & -0.2512 & -0.1732 & 1.0000 & & & \\
loglife & 0.4568 & -0.7125 & 0.0500 & -0.0676 & -0.2735 & -0.0564 & 1.0000 & & \\
$\boldsymbol{L A W}$ & 0.4695 & -0.6270 & 0.0435 & 0.0241 & -0.3827 & -0.1041 & 0.4733 & 1.0000 & \\
SEM & 0.5078 & -0.5243 & -0.1154 & -0.0353 & -0.0941 & -0.1331 & 0.4433 & 0.3473 & 1.0000 \\
\hline
\end{tabular}

In the correlation matrix all values are less than 0.90 which means there is no multicollinearity in the model. Results show that institutions are positively corelated with economic growth. Original STATA result is appended as Appendix 2.

Selection of Model: In order to choose the most appropriate model, there are three options: Constant Coefficient/Pooled OLS model with the assumption that constant/s does not vary across countries or years. It also assumes that there are no significant individual effects. Fixed Effect Model is to enable the model to control for omitted variables that vary between countries while being constant over time. Random Effect Model is about having no significant variable between countries while there are significant time-based effects.

The Constant Coefficients/Pooled OLS Model: The constant coefficient model (OLS) assumes that there is neither statistically significant country nor statistically significant temporal effects. The results of the regression are given below with coefficients and their corresponding significance.

Table 3 Constant Coefficient Model

\begin{tabular}{|lc|}
\hline Variables & Pooled OLS \\
\hline \multirow{2}{*}{ INS } & $0.259^{* *}$ \\
& $(0.121)$ \\
logfer & $0.792^{* * *}$ \\
& $(0.168)$ \\
GCR & $0.00488^{* * *}$ \\
& $(0.00140)$ \\
INV & 0.00383 \\
& $(0.00238)$ \\
GINI & $0.00414^{*}$ \\
& $(0.00223)$ \\
STBL & $-0.0453^{*}$ \\
loglif & $(0.0249)$ \\
LAW & $7.564 * * *$ \\
& $(0.701)$ \\
& $0.250^{* * *}$ \\
\hline
\end{tabular}




\begin{tabular}{|lc|}
\hline SEM & $0.00762 * * *$ \\
& $(0.000910)$ \\
Constant & $-25.53 * * *$ \\
& $(3.072)$ \\
Observations & 213 \\
Number of CNTRY & 25 \\
\hline
\end{tabular}

Standard errors in parentheses

$$
* * * \mathrm{p}<0.01, * * \mathrm{p}<0.05, * \mathrm{p}<0.1
$$

The results from the constant coefficient/pooled OLS model denotes that there is a positive correlation between institutions and economic growth at a 5\% significance level. Detailed STATA result is appended as Appendix 3.

Fixed effects model: If the variables differ for countries but static for time, a fixed effect regression is used to control for omitted variables. The FE model is used so that the estimated coefficients cannot be biased on the basis of omitted time invariant characteristics, for example, ethnicity, race, gender etc. The following table indicates the results for the fixed effects model.

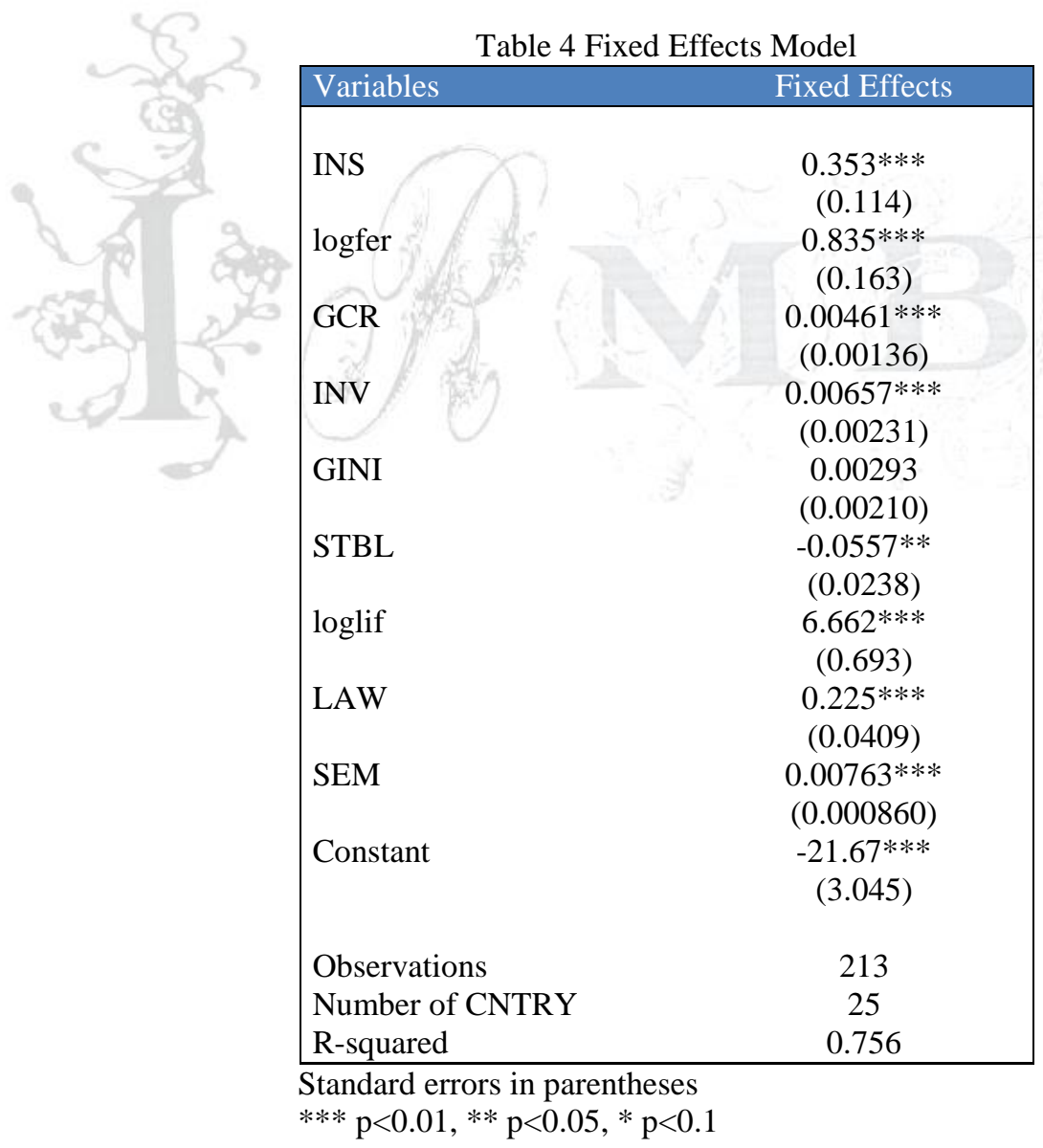

The results of the Fixed Effect model show institutions as highly significant at $1 \%$ confidence level. It indicates $76 \%$ R square. Detailed STATA result is appended as Appendix 4. 
Random effects model: The random effects model is useful if there might be omitted variables which are constant over time, while there are variations between them. In this model, time invariant variables are included in the regression as regressors.

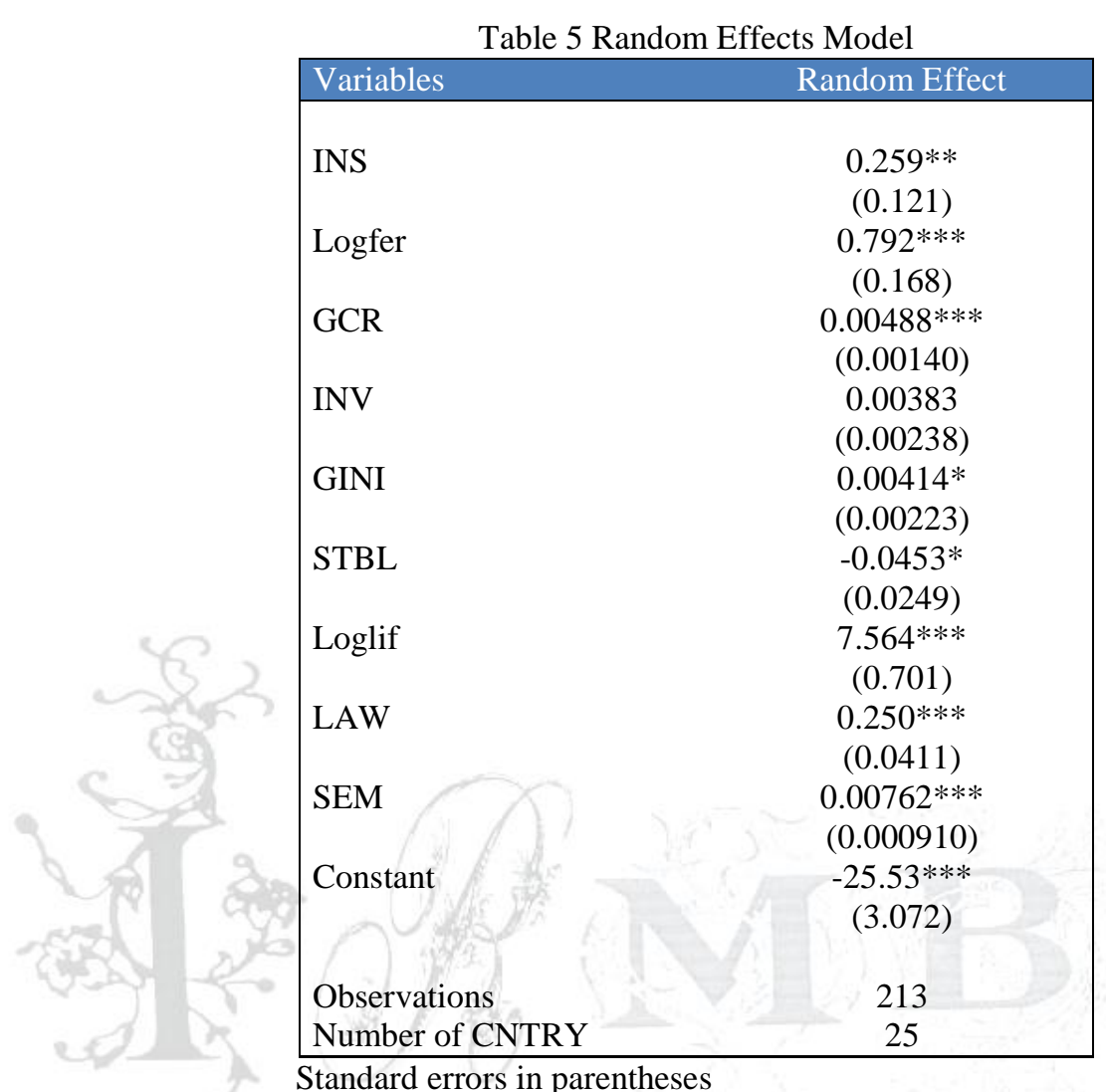

Standard errors in parentheses

$* * * \mathrm{p}<0.01, * * \mathrm{p}<0.05, * \mathrm{p}<0.1$

The results from the random effect model perform slightly worse than fixed effects model. Significance of institutions drop from $1 \%$ to $5 \%$ in random effect model. BPLM and Hausman tests are done to select the most efficient model. Detailed STATA result is appended as Appendix 5.

\section{Breusch and Pagan Lagrange Multiplier test:}

In order to identify any omitted country or time specific effects, Breusch and Pagan Lagrange Multiplier test is used to determine whether the intercept has the same value across countries and years. The Breusch and Pagan Lagrange Multiplier test give the following results:

Table 6 Breusch and Pagan Lagrange Multiplier test results

\begin{tabular}{|l|c|}
\hline Test: $H_{\circ}:$ & Var $(\mathbf{u})=0$ \\
\hline Chibar $2(01)=$ & 306.66 \\
\hline Prob $>$ chibar2 = & 0.0000 \\
\hline (V_b-V_B is not positive definite $)$ & \\
\hline
\end{tabular}

As the $\mathrm{P}$ value of chi2 distribution is significant so null hypothesis is rejected. Random Effect model is more efficient than pooled OLS. Detailed STATA result is appended as Appendix 6. 
Hausman test: Hausman test is used to identify whether to use the random or fixed model. It can help to check if there is a significant correlation between the unobserved random effect and the regressors and if there is no correlation then the model should follow random effect. On the other hand, if there is correlation then the random effects model would show inconsistency in estimates and appropriate model would be fixed effects. If the difference is not significant, it is safe to use the random model whereas if the $\mathrm{P}$ value is significant, the fixed effects model should be used. Hausman test produces the following results:

Table 7 Hausman Test Results

\begin{tabular}{|c|c|}
\hline Test: $H_{\circ}:$ & difference in coefficients not systematic \\
\hline $\operatorname{chi} 2(9)=(b-B)^{\prime}\left[\left(V \_b-V \_B\right)^{\wedge}(-1)\right](b-B)=$ & 125.88 \\
\hline Prob $>$ chi2 $=$ & 0.0000 \\
\hline
\end{tabular}

The results of Hausman test indicate that the difference between the models is significant. The random effect estimates are inconsistent. So, the fixed effect model is more robust for this model. Detailed STATA result is appended as Appendix 7.

Heteroscedasticity: Heteroscedasticity is present when the variance of the residuals is not-constant making it violation of one of the Gauss-Markov assumptions under which our statistical inference can be justified. Presence of heteroscedasticity means coefficient estimates are unbiased and consistent but are not efficient and the estimated variances are biased while confidence intervals and significance tests are not valid (Wooldridge, 2009). In this paper we use the Modified Wald test for group-wise heteroskedasticity.

Table 8 Modified Wald test for group-wise heteroskedasticity

\begin{tabular}{|lc|}
\hline H0: $\operatorname{sigma}(i)^{\wedge} 2=0$ & $\operatorname{sigma}^{\wedge} 2=0$ for all $i$ \\
chi2 $(25)=$ & 5627.96 \\
\hline Prob $>$ chi $2=$ & 0.0000 \\
\hline
\end{tabular}

The null is homoskedasticity (or constant variance). The significant $p$ value ( $p$-value $>$ chi 2 is $<a$ ), shows that we can reject the null hypothesis and conclude that there is heteroskedasticity. Detailed STATA result is appended as Appendix 8.

Wooldridge test for serial autocorrelation: In a classical regression model, there is an assumption of independence of disturbances from observation to observation. If this assumption is violated then problem of autocorrelation emerges. In order to test autocorrelation in panel data, Wooldridge (2002) has designed a simple test which was further authenticated by Drukker (2003).

Table 9 Wooldridge test for autocorrelation in panel data Results

\begin{tabular}{|l|c|}
\hline$H_{0}$ & no first-order autocorrelation \\
\hline F $(1,14)$ & 44.286 \\
\hline Prob $>$ F & 0.0000 \\
\hline
\end{tabular}

The above-mentioned results show that the model suffers from autocorrelation. There is a possibility that autocorrelation exists because of model miss-specification or an omitted lagged dependent variable. However, autocorrelation is tested for macro panels with long time series (over 20-30 years). Autocorrelation is not a problem in micro panels. The paper here, has 20 countries so it is at the borderline. The model shall proceed with correction of autocorrelation. Detailed STATA result is appended as Appendix 9.

Dynamic Panel Model: The result from autocorrelation test suggests that the model seems to suffer from auto-correlation which can be corrected by estimating a dynamic panel model based on the Generalised 
Method of Moment (GMM) estimation (Arellano \& Bond 2002). Lagged variable when included, shows persistence over regressor $\left(\log G D P_{\text {it }}\right)$ and error term $\left(\varepsilon_{\text {it }}\right)$. For Dynamic panel data model estimation, Arellano-Bond technique is used to include one lagged variable. With inclusion of one lagged variable the new Dynamic Panel Model is as follows:

\section{$\operatorname{LogGDP}_{\text {it }}=\beta_{1}$ Ins $_{\text {it }}-\beta_{2} \operatorname{LogFer}_{\text {it }}-\beta_{3} G_{C R}$ it $+\beta_{4} \operatorname{Inv}_{\text {it }}-\beta_{5}$ Gini $_{\text {it }}+\beta_{6}$ Stbl $_{\text {it }}+\beta_{7} \operatorname{LogLif}_{\text {it }}+\beta_{8} \operatorname{Law}_{\text {it }}+\beta_{9}$ $\operatorname{SEM}_{\text {it }}+\beta_{10} \operatorname{LogGDP}_{\mathrm{it}-1}+\alpha_{\mathrm{i}}+\epsilon_{\mathrm{it}}$}

Where, $\operatorname{LogGDP}_{\mathrm{it}-1}$ is lagged variable for the dependent variable. With lagged variables introduced, the results are as follows:

Table 10 Dynamic Effects Model

\begin{tabular}{|lc|}
\hline Variable & Dynamic \\
INS & $0.366^{* * *}$ \\
Logfer & $(0.116)$ \\
& $0.853^{* * *}$ \\
GCR & $(0.166)$ \\
& $0.00470^{* * *}$ \\
INV & $(0.00138)$ \\
& $0.00646^{* * *}$ \\
GINI & $(0.00232)$ \\
& 0.00283 \\
STBL & $(0.00216)$ \\
& $-0.0576^{* *}$ \\
loglif & $(0.0240)$ \\
& $6.597 * * *$ \\
LAW & $(0.704)$ \\
& $0.215^{* * *}$ \\
SEM & $(0.0425)$ \\
& $0.00770^{* * *}$ \\
laggdp & $(0.000866)$ \\
& -0.00154 \\
Constant & $(0.00243)$ \\
& $-21.40^{* * *}$ \\
Observations & $(3.092)$ \\
Number of CNTRY & \\
R-squared & 212 \\
Standard errors in parentheses & 25 \\
$* * * p<0.01, * * \mathrm{p}<0.05, * \mathrm{p}<0.1$ & \\
& \\
& \\
&
\end{tabular}

With lagged variables introduced, the model produces the most efficient results. Institutions are highly significant with $1 \%$ change in institution will bring $0.36 \%$ change in economic growth. The results speak in favour of institutions' positive impact on economic growth. Detailed STATA result is appended as Appendix 10. 


\section{Conclusion}

The paper demonstrates the impact of institutions on economic growth through theoretical and empirical evidences. The paper establishes a model on the basis of 32 countries from Latin America, South Asia and East Asia over a period of twenty countries. The model is inspired by Barro (1996) and Rodrick (2000) which shows positive correlation of institutions on economic growth along with control variables such as fertility, investment ratio, government size, inequality, political stability and rule of law. The model required a lagged dependent variable to ratify the autocorrelation among variables. With inclusion of lagged variable, the model has come up as a dynamic panel data model with highly significant positive relation of institutions with economic growth.

The model predicted negative signs for fertility rate, government consumption ratio and inequality and positive signs for the rest. However, the results have indicated that they all have positive relation with economic growth. Signs of control variables are linked with the socio-economic conditions of the selected countries. High fertility rate may have negative impact on economic growth per capita but it may not be the case for subsistence or low-capital economies which is the case with majority among the set of 32 countries. Inequality is being used as a control variable, which somehow validates Kuzent's curve theory that inequality increases in initial levels of economic growth. This is valid for the countries which are analysed for this model. Latin America, South Asia and East Asia are regions with emerging economics. Political stability has turned out to have an insignificant negative impact on economic growth. East Asian countries have high economic growth rate as compared to Latin America and South Asia but they are generally authoritarian regimes as compared to the other two regions. Appendix 11 shows institutional development over the years for 32 countries.

Although the model produces highly significant result, the research faces some limitations in terms of a smaller number of countries and limited time frame. The paper suggests further research on the model with widened scope and expanded number of countries covering a longer period of time. The results are generally consistent with Barro (1996) and Rodrick (2000) in which they have established positive correlation with democracy and institutions. The model shows highly significant positive correlation of institutions and economic growth with relevant contributing factors and enabling environment.

\section{References}

Acemoglu, D. (2003). 'The form of property rights: Oligarchic vs. democratic societies', unpublished, MIT.

Acemoglu, D., Johnson, S. and Robinson, J. A. (2001). 'The colonial origins of comparative development: An empirical investigation', American Economic Review, 91(5)

Ahmad, M., \& Hall, S. G. (2017). Economic growth and convergence: Do Institutional proximity and spill overs matter? Journal of Policy Modeling 39, 1065-1085

Bardhan, P. (1989). 'The new institutional economics and development theory: A brief critical assessment', World Development, 17(9), pp. 1389-95.

Bardhan, P. (2005). Institutions matter, but which ones?. The Economics of Transition, 13(3), pp.499-532.

Bardhan, P. and Udry, C. (1999). Development Microeconomics, Oxford: Oxford University Press.

Barro, R. and Sala-i-Martin, X. (2006). Economic growth. Cambridge, Mass.: The MIT Press.

Barro, R., (1997). Determinants of Economic Growth: A Cross-Country Empirical Study Cambridge, MIT Press

Barro, Robert J. (1996a)."Democracy and Growth." Journal of Economic Growth 1, no. 1, 1-27.

Barro, Robert J. (1996b). Determinants of Economic Growth, A Cross country empirical study. NBER Working Paper 5698. National Bureau of Economic Research.

Blundell and Bond, S. (2000), GMM Estimation with persistent panel data: an application to production functions. Econometric Reviews,19(3), 321-340. 
Boix, C., (2011). Democracy, Development and the International System. The American Political Science Review.

Busch, L. A. and Muthoo, A. (2002). 'Power and inefficient institutions', unpublished, Essex University, UK.

Chang H.J. (2001). Breaking the Mould, An institutionalist political economy, alternative to the neoliberal theory of the market and the state. United Nations Research Institute for Social Development.

Chang, H. and Nayyar, D. (2007). Institutional change and economic development. New York: United Nations University Press.

Cheibub, J.A et al. (2009) Democracy and dictatorship revisited. Public Choice Vol 143

Doucouliagos, H. et al. (2008). Democracy and Economic Growth: A Meta-Analysis. American Journal of Political Science.

Drury, A., Krieckhaus, J. and Lusztig, M. (2006). Corruption, Democracy, and Economic Growth. International Political Science Review, 27(2), pp.121-136.

Gerring, J., et al (2005). Democracy and Economic Growth: A Historical Perspective. Cambridge University Press

Glaeser, E.L., et al. (2004). Do institutions cause growth? Journal of Economic Growth, Vol 9.

Gurvich, E. (2016). Institutional constraints and economic development. Russian Journal of Economics, 2(4), pp.349-374.

Hadenius, A. (1992). Democracy and Development, Cambridge University Press.

Kriechkaus, J. (2006). Democracy and Economic Growth: How Regional Context Influences Regime Effects. British Journal of Political Science, 36(02), p.317.

Mankiw, N., Romer, D. and Weil, D. (1992). A Contribution to the Empirics of Economic Growth. The Quarterly Journal of Economics, 107(2), pp.407-437.

North, D. (1989). Institutions and economic growth: An historical introduction. World Development, 17(9), pp.1319-1332.

Ostrom, E. (2007). Challenges and growth: the development of the interdisciplinary field of institutional analysis. Journal of Institutional Economics.

Polity IV Project, Marhsall, M.G., (2013). http://www.systemicpeace.org/polity/polity4x.htm

Robinson, James A, Daron Acemoglu, and Simon Johnson. 2005. "Institutions as a Fundamental Cause of Long-Run Growth". Handbook of Economic Growth 1A:386-472. https://economics.mit.edu/files/4469

Rodrick, D. (1999). Democracies pay higher wages. The Quarterly Journal of Economics. Vol 114. Oxford University Press

Rodrick, D., (2000). Institutions for High Quality Growth, What they are and how to acquire them. Working Paper 7540. National Bureau of Economic Research, Cambridge

Rodrik, D., Subramanian, A. and Trebbi, F. (2004). 'Institutions rule: The primacy of institutions over geography and integration in economic development', Journal of Economic Growth, 9(2), pp. 131-65.

Romer, D., \& Frankel, J.A., (1999). Does Trade Cause Growth. The American Economic Review.

Sobel, R. and Coyne, C. (2011). Cointegrating Institutions: The Time-Series Properties of Country Institutional Measures. The Journal of Law and Economics, 54(1), pp.111-134.

Wooldridge, et al (2014). Econometrics, Custom Edition, University of Manchester, CENGAGE Learning. World Development Report (2002). Building Institutions for Markets. The World Bank

Zakria, M. \& Fida, B.A. (2009). Democratic Institutions of Economic Growth in Pakistan: Some evidence from the time series analysis. Pakistan Institute of Development Economics. 


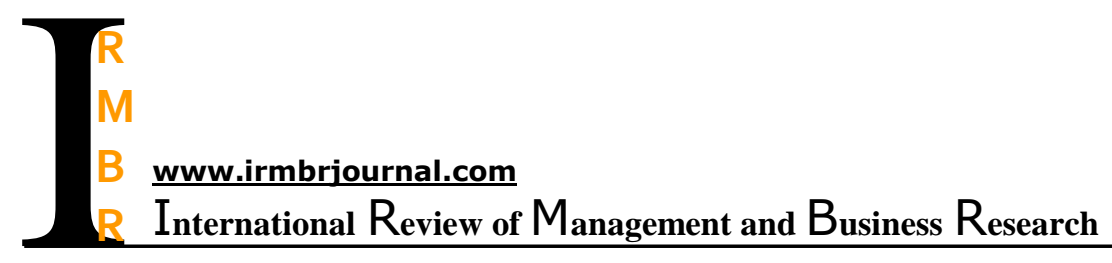

March 2021

International Review of Management and Business Research

Vol. 10 Issue.1

\section{Appendices}

Appendix 1 Data Summary

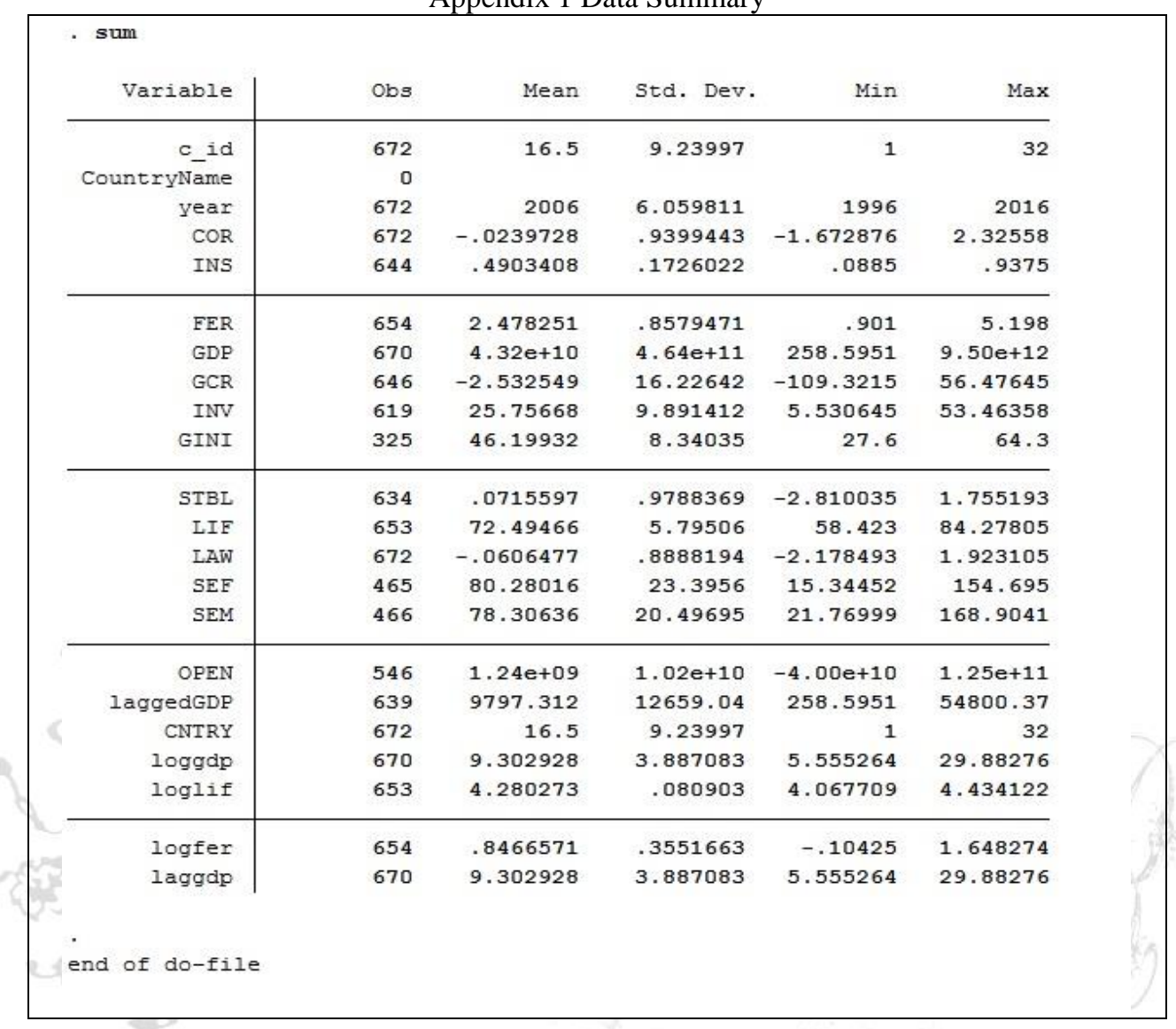

Appendix 2 Multicollinearity Test Results

\begin{tabular}{|c|c|c|c|c|c|c|c|c|c|}
\hline & INS & logfer & GCR & INV & GINI & STBL & $\log l i f$ & LAW & SEM \\
\hline INS & 1.0000 & & & & & & & & \\
\hline $\operatorname{logfer}$ & -0.3070 & 1.0000 & & & & & & & \\
\hline GCR & 0.0366 & 0.0709 & 1.0000 & & & & & & \\
\hline INV & -0.2870 & -0.2168 & 0.2369 & 1.0000 & & & & & \\
\hline GINI & -0.1450 & 0.4430 & -0.2405 & -0.3445 & 1.0000 & & & & \\
\hline STBL & 0.0081 & 0.1838 & 0.2253 & -0.2512 & -0.1732 & 1.0000 & & & \\
\hline $\log l i f$ & 0.4568 & -0.7125 & 0.0500 & -0.0676 & -0.2735 & -0.0564 & 1.0000 & & \\
\hline IAW & 0.4695 & -0.6270 & 0.0435 & 0.0241 & -0.3827 & -0.1041 & 0.4733 & 1.0000 & \\
\hline SEM & 0.5078 & -0.5243 & -0.1154 & -0.0353 & -0.0941 & -0.1331 & 0.4433 & 0.3473 & 1.0000 \\
\hline
\end{tabular}


Appendix 3 The Constant Coefficients/Pooled OLS Model Detailed Results

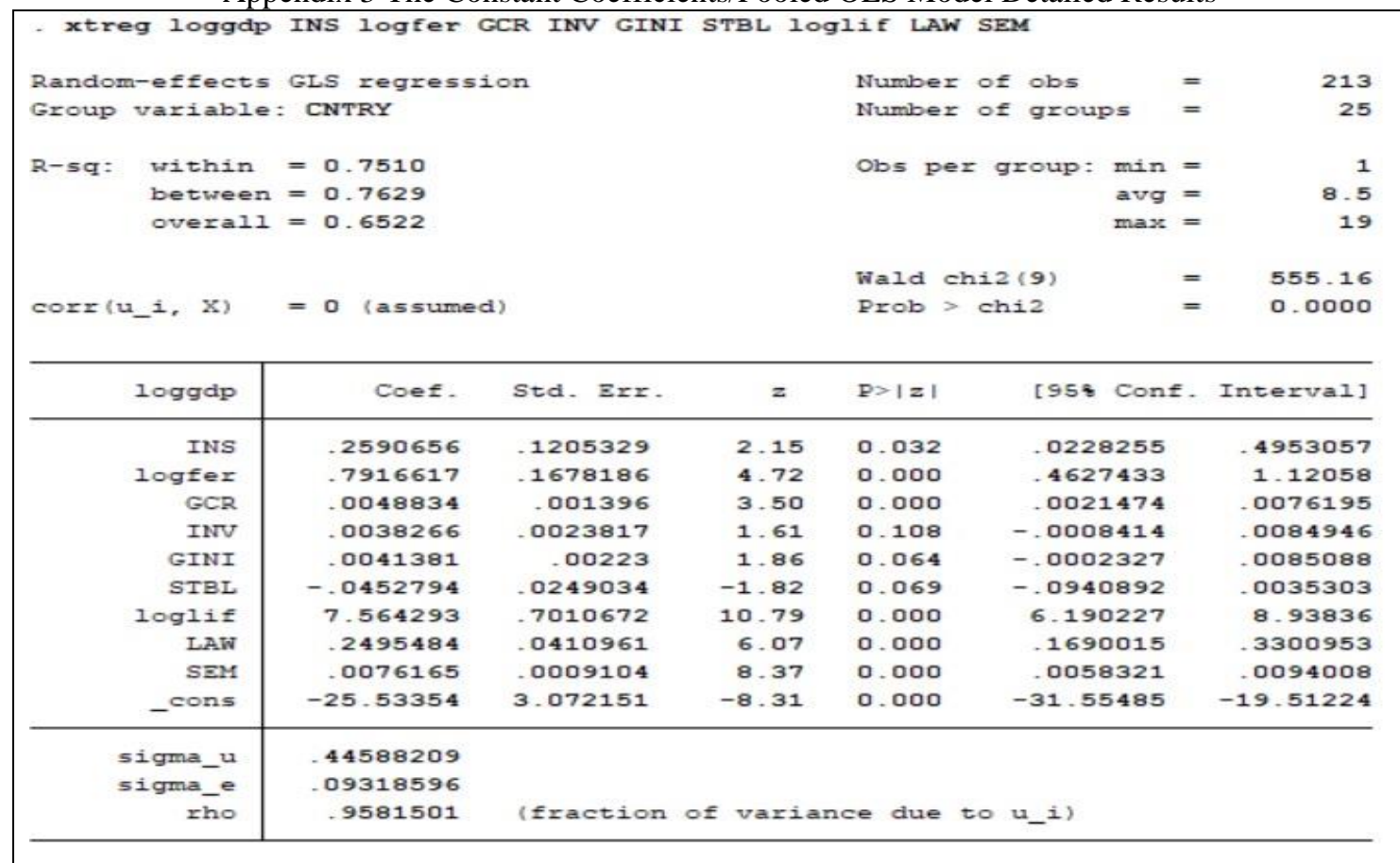

Appendix 4 The Fixed Effect Model Detailed Results

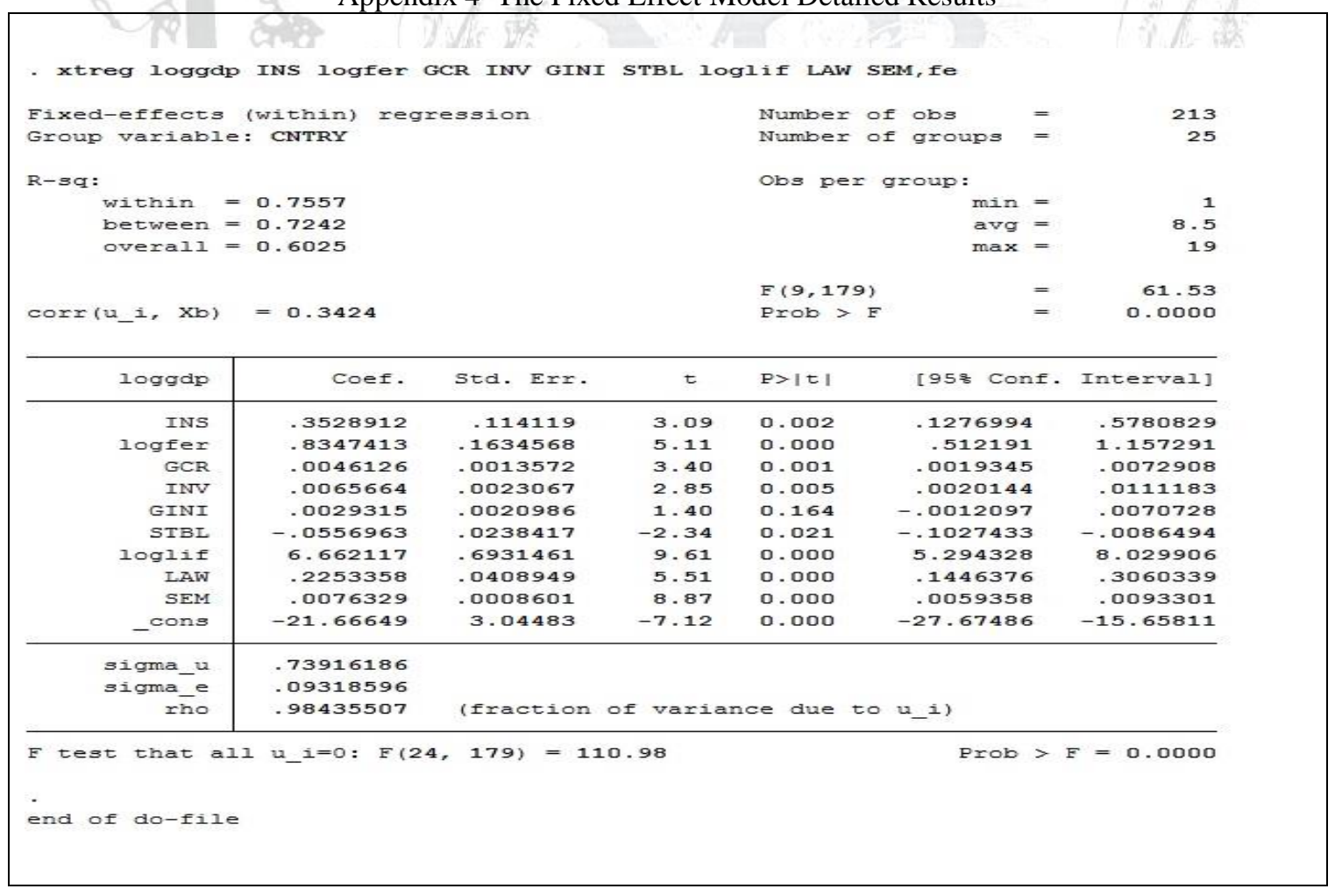


Appendix 5 The Random Effect Model Detailed Results

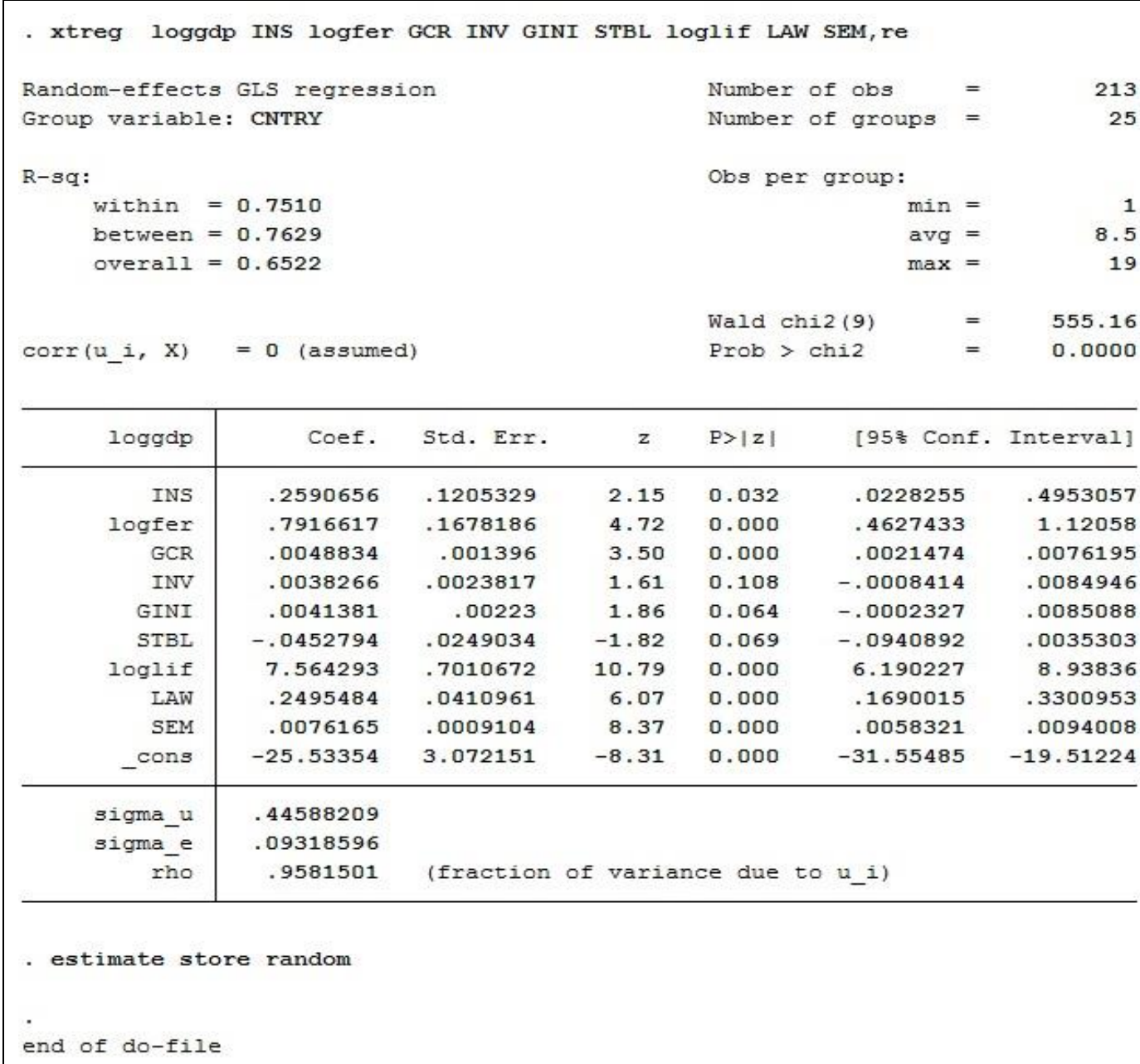

Appendix 6 Breusch and Pagan Lagrange Multiplier Test Results

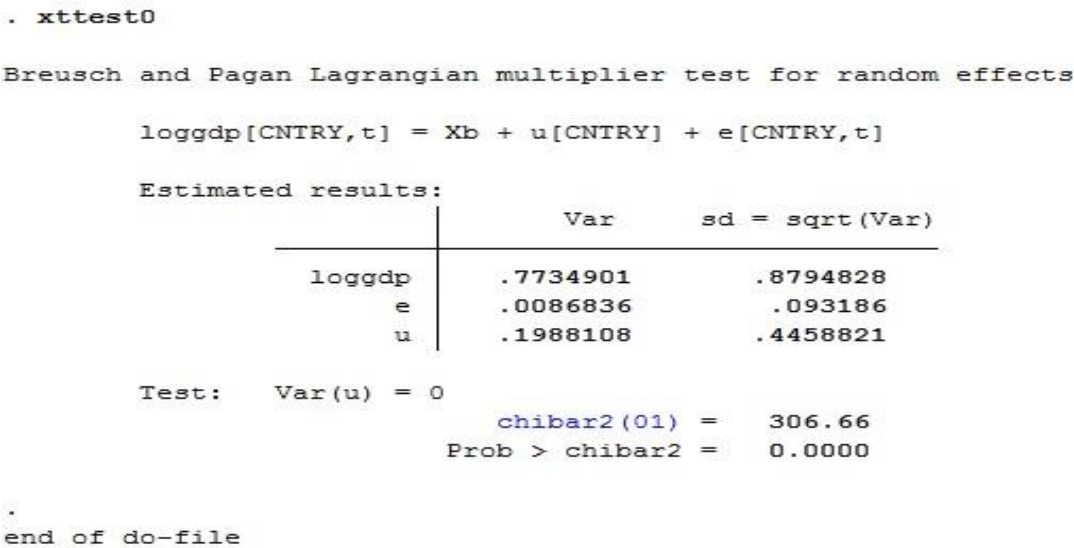


www.irmbrjournal.com

March 2021

International Review of Management and Business Research

Vol. 10 Issue.1

Appendix 7 Hausman Test Detailed Results

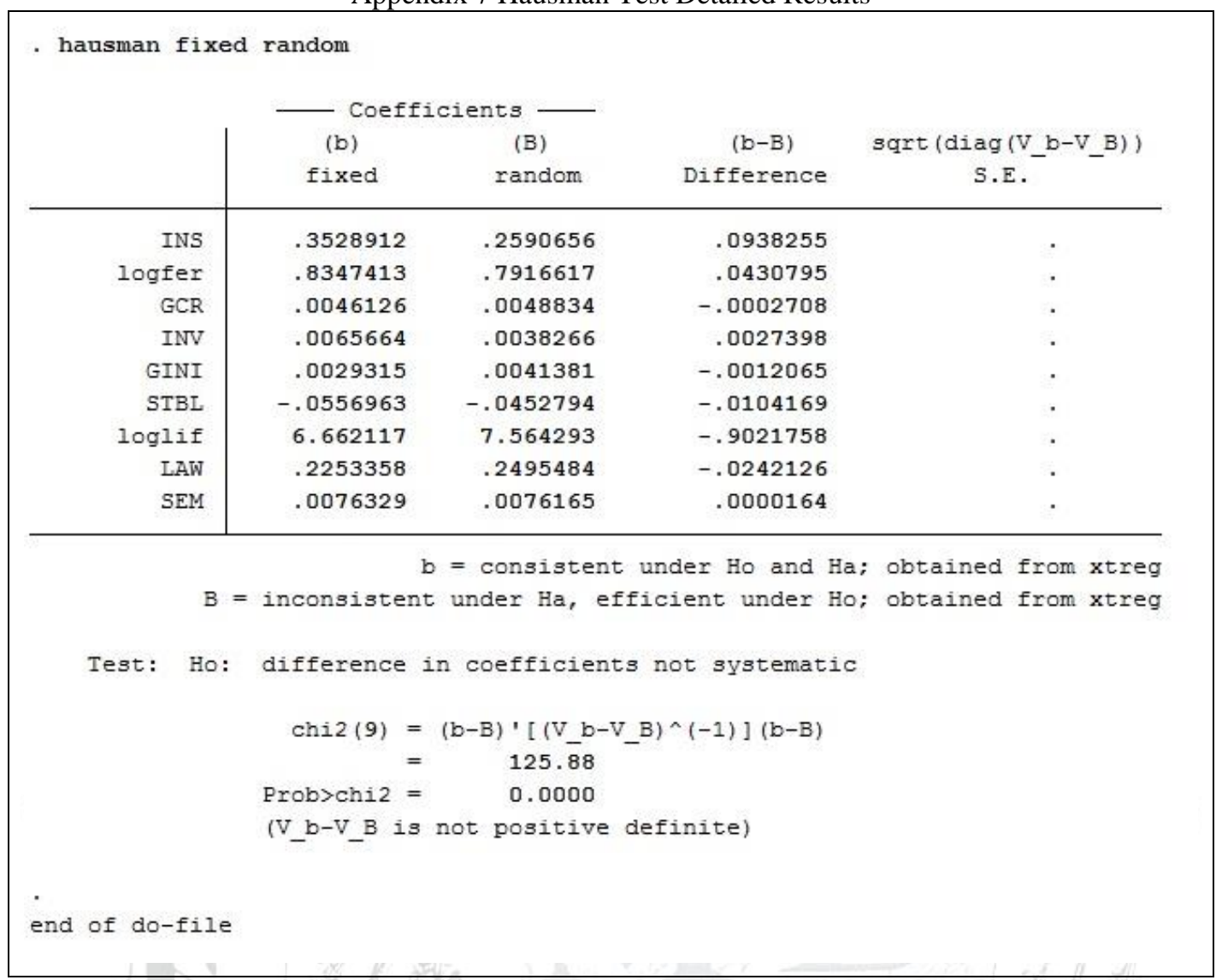

Appendix 8 Modified Wald test for group-wise heteroskedasticity Result

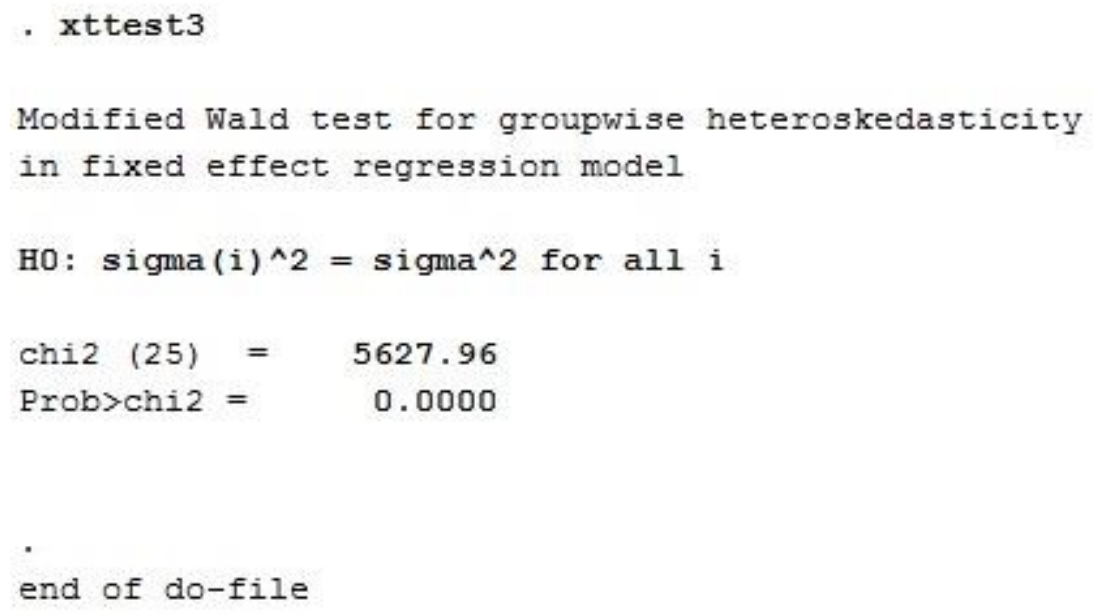




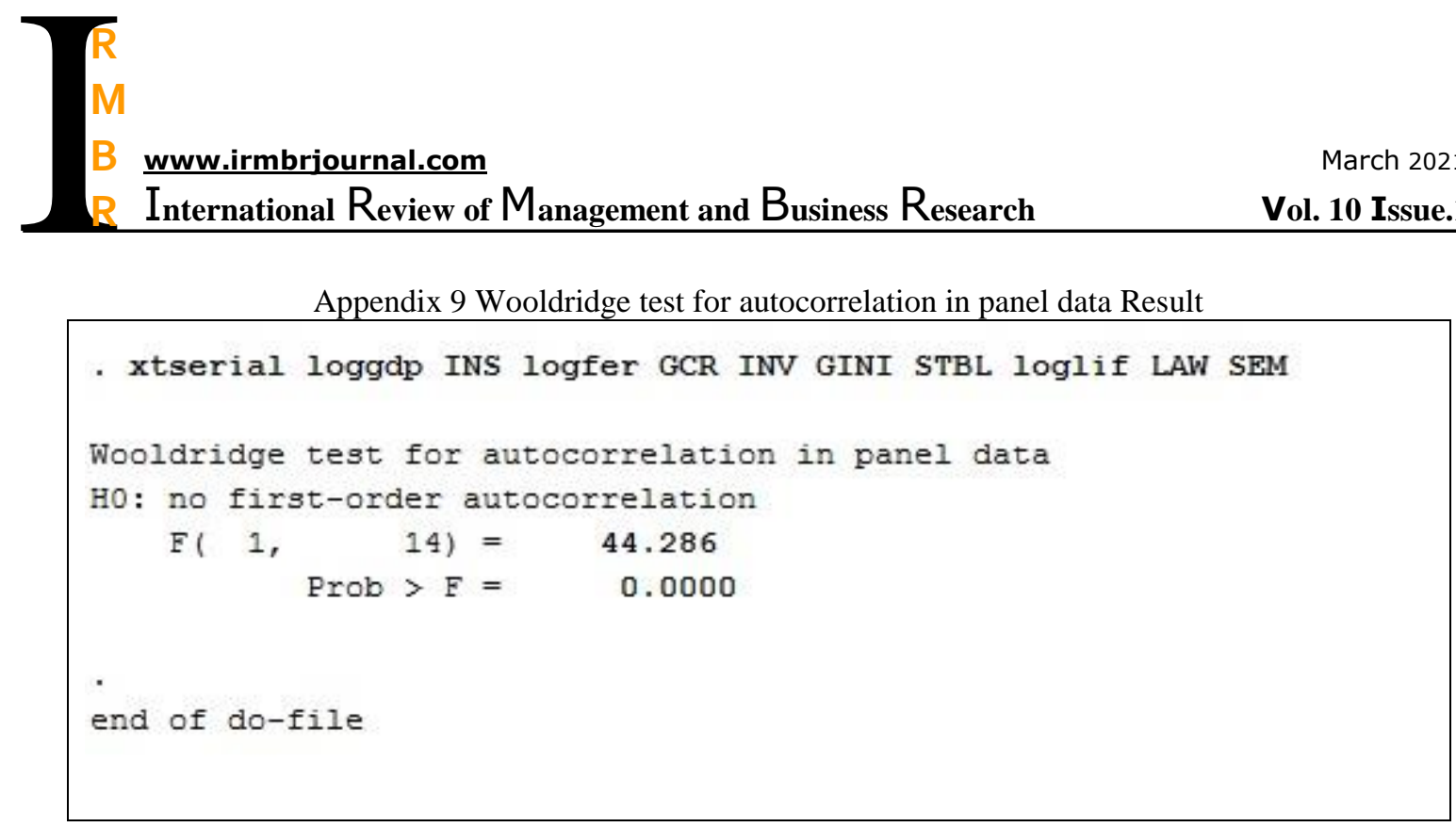

Appendix 10 Dynamic Panel Data Result

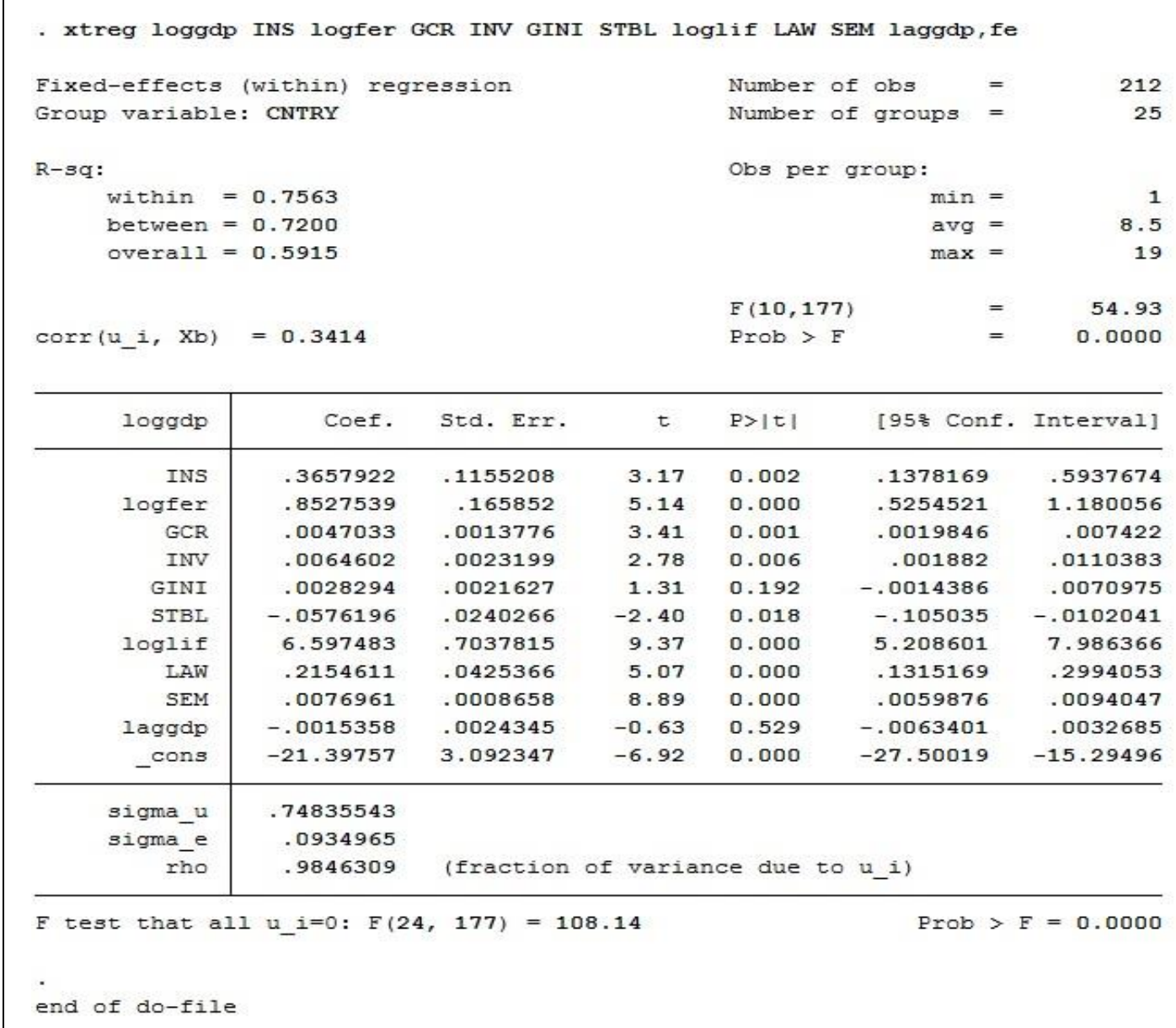


Appendix 11 Institutional Development in 32 countries

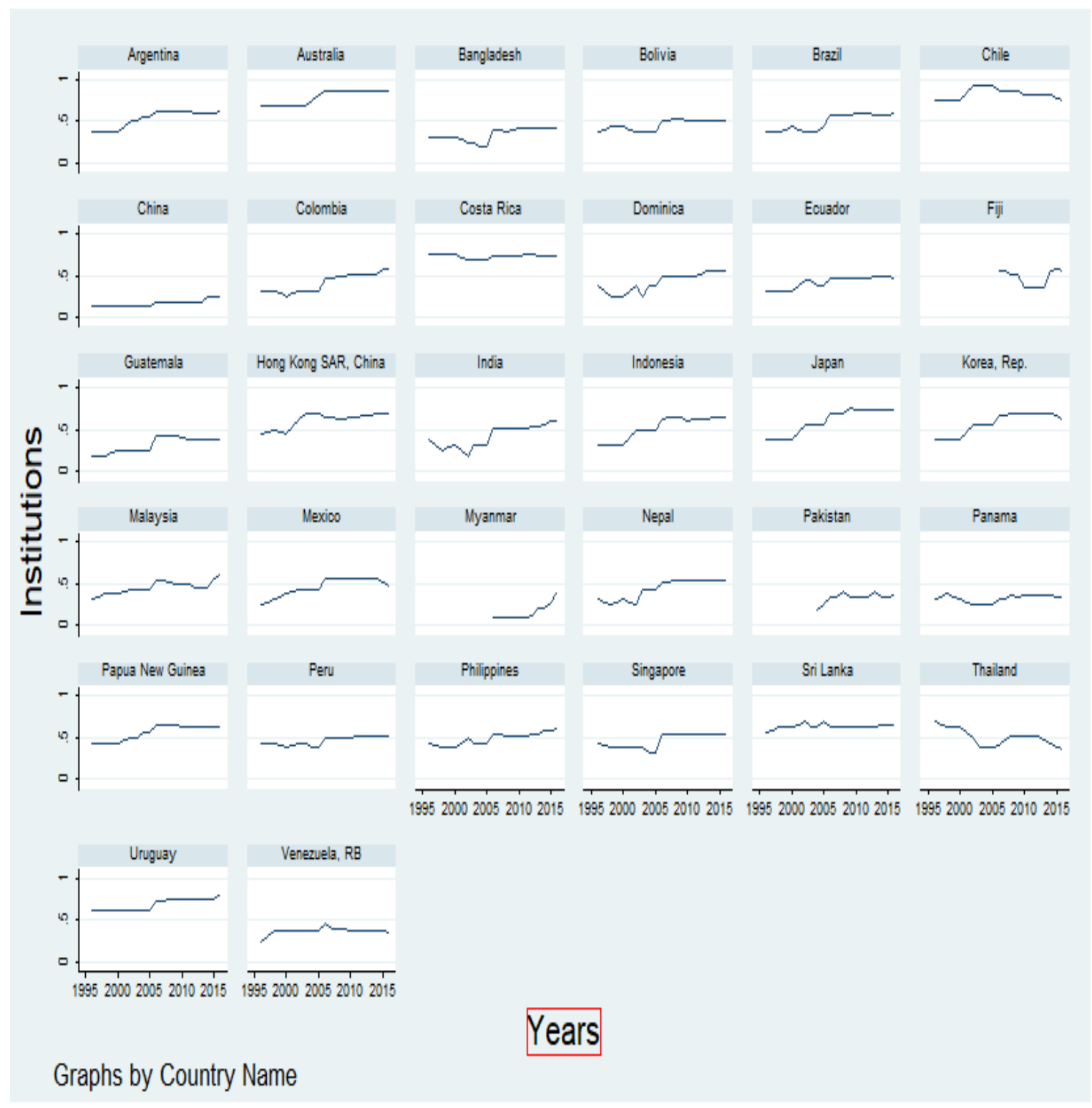

